to your readers that a screen, whose valuable properties seem even now to be scarcely at all known, should be noted in your columns.

It simply consists of a sheet of French tracing-paper, of a kind which possesses a remarkably dull, non-reflecting surface. With this screen and only an oil-lamp lantern, it is quite easy to show pictures well to a couple of hundred people in a room fairly well lighted-sufficiently lighted indeed to enable note-taking or reference to books to be accomplished with perfect easeprovided that extraneous lights are not placed behind the screen.

It was to Mr. George Smith, of the Sciopticon Company, that I was indebted, four years ago, for the knowledge of this fact; which, with considerable lantern experience, I scarcely knew how to believe, until I had myself verified it.

At present, however, the tracing-paper cannot, I believe, be obtained more than three to four feet square.

Charles J. Taylor

Toppesfield Rectory, Essex, February I 7

\section{Fuller's Earth as a Filter}

WHERE the fuller's earti is dug from the Bedfordshire green- sand it is held in much repute for its efficacy in removing impurities from turbid water. ${ }^{x}$ In addition to the other uses to which it is here applied, dealers take it around through the fen countries, and dispose of it for clarifying the peaty water, ${ }^{2}$ often the only supply obtainable in those districts.

I shall esteem it a favour on the part of the readers of NATURE residing on the Greensand or Oolites of the southern counties to notify if these filtering properties of the Bedfordshire fuller's earth are in any way unique - in so far as they appear withheld from that of other places?--as at Reigate, Bath, \&c., where fuller's earth is known to them to be dug.

Bedford, February 23

\section{A. G. Cameron}

\section{The Boomerang in India}

IN Gustav Oppert's work "On the Weapons, Army Organisation, and Political Maxims of the Ancient Hindus," the boomerang is mentioned as being among the weapons, especially in Southern India, and made of various materials-iron, ivory, and wood. Are any specimens to be found in our museums here, or would any private persons who may happen to possess any, kindly allow me to inspect them ?

ARThuR Nicols

\section{THE CAMERA OBSCURA IN TORPEDO WORK ${ }^{1}$}

$A \mathrm{~T}$ the time of the last Austro-Italian war, in $\mathbf{I} 866$, the A Austrian Government made the greatest efforts to protect its harbours from an attack of the Italian fleet. Torpedoes were placed in great numbers in the harbours, and the greatest vigilance was enjoined on all the commandants of such places.

The accompanying illustration represents a novel application of the camera for use at the observing or firing post of a party belonging to the military telegraph. The torpedoes are placed along certain concentric lines, very close to each other, and at a certain depth below the sur-

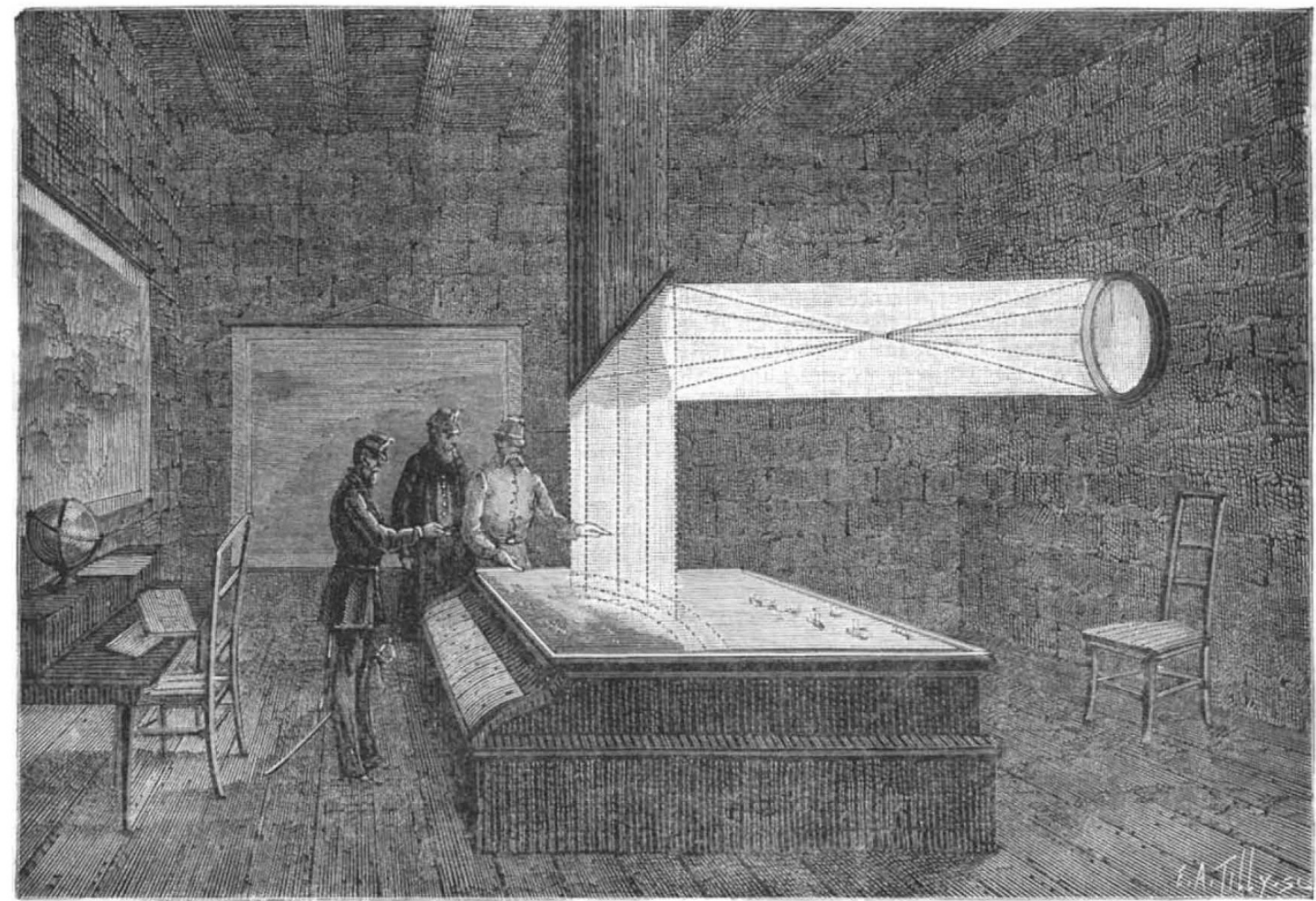

face of the water, no sign of their presence being apparent. A metallic wire connects each of them with a post of observation situated on the coast at a point sufficiently elevated to permit of the port being seen. According to well-known optical laws, an image of the port is formed on the glass. Black points marked on that image indi-

\footnotetext{
I Frøm La Nature.
}

cates the exact position of each torpedo ; these points are all numbered, each number corresponding with that on a particular key of a keyboard. To press one of these keys with the finger is sufficient to place the corresponding

I Geol. Mag., February, 1885 .

2 A brief account of the method in use in the fen districts of Cambridgeshire and Lincoln will appear shortly. 
torpedo in communication with an electric battery, by means of a metallic wire which connects it with the port, and so cause an explosion.

\section{THE CONTINUITY OF THE PROTOPLASM IN PLANT TISSUE}

THE translation of Dr. Schaarschmidt's paper in a recent number of NATURE (January 29th, I 885 ) gave those who, like myself, are unable to read Hungarian, full details both of his researches and views, and as one much interested in the subject of "the continuity of the protoplasm," I should like to be allowcd to make a few remarks upon it.

To refer first of all to a matter of minor importance with reference to sieve-tubes, I see that Dr. Schaarschmidt says: "The first direct observation was made in 1854 by Hartig, and not by Sachs, as Walter Gardiner states." This refers to the opening passage of my paper in the Arbeiten des Botanischen Instituts in Würzburg, Band III., Heft I., where I say : "A most important addition was made to our knowledge of the histology of tissues in I 863 by Sachs, and in the following year by Hanstein, when they demonstrated that in the sieve-tubes first described by Hartig there are perforations in the transverse walls, \&c." I made that statement, relying, as I still do, on the authority of Prof. Sachs's text-book (English edition, I882, p. 89), since it scemed to me that Hartig's observation, which could not be confirmed by "Mohl and others," was actually proved and demonstrated beyond doubt by Sachs and Hanstein, and, moreover, in fresh and not in macerated tissue.

With respect to the main subject under immediate consideration, I shall first make one or two general statements as to the continuity of the protoplasm in plant tissues. In my paper in the Würzburg Arbeiten, to which $I$ have already referred, I have spoken of two appearances of continuity: one which I speak of as direct, and the other as indirect. By direct or unbroken continuity, I mean the appearance of a thick protoplasmic process, extending between, and uniting the protoplasmic contents of two contiguous cells: the pits forming one continuous canal, and being uninterrupted by a pit-closing membrane. In this case, therefore, the idea of open pits is necessitated. By indirect continuity I mean the existence of a pit-closing membrane between the two opposite protoplasmic processes in the pits: the membrane being perforated in a sicve-like manner, and thus allowing the two protoplasmic processes to become united to one another by means of delicate protoplasmic filaments which traversc the pit-closing membrane. I further stated that my observations led me to believe that a pit-closing membrane was present in all cases, and that the appearance of a direct unbroken continuity is fallacious. (See also Roy. Soc. Proc., December I 3 th, I 883 .)

Turning now to the consideration of the observations made upon the Florideae, I shall have to differ somewhat with Dr. Schaarschmidt; but, while I do so, I wish it to be quite clearly understood that I do not in the least undervalue the work of those investigators to whom I refer, and who, according to my view, have not actually demonstrated a continuity of the protoplasm from cell to cell, but have only observed facts which render the existence of such a continuity extremely probable. Thus, since I regard the perforation of the pit-closing membrane as proving continuity, I hold that the observations of Bornet, Perceval Wright, and Agardh (I have unfortunately not seen KolderupRosenvinge's paper) have not demonstrated continuity, but have demonstrated that the pit-protoplasm clings with remarkable tenacity to the pit-closing membrane. Hick has simply repeated the observations of these investigators, and of his results the same may be said. Since, therefore, Schmitz ( 1883 ) has found that a pit-closing membrane does cxist ; that it is perforated in a sieve-like manner, and that therefore the continuity is not direct, but indirect, it seems to me that to him alone belongs the credit of having demonstrated the continuity of the protoplasm in the Florideae, and I have myself (Proc. Camb. Phil. Soc., February I Ith, 1884) been able to confirm his results as to the existence of the closing membrane in question.

In considering the history of the subject, and leaving sieve-tubes out of the question, it is clear that Tangl's observation (1880) on the endosperm cells of Phoenix and Sirychnos was the first new discovery in the direction of the continuity of the protoplasm between neighbouring cells. Then came Strasburger's classic work on the cellwall ("Bau und Wachsthum der Zellhäute," I 882) ; his observations on the porosity of the pit-closing membranes, and his valuable suggestions as to the probability of cellwall perforation, together with the citation of instances which already occurred, and his cxtremely interesting observation with regard to the swarm-spores of Vaucheria. Naturally Volvox, Pandorina, and the zoospores of Hematococcus offer other examples of the perforation of the cell-membranc by protoplasm.

After Strasburger came Russow. Russow read his first paper at the January meeting of the Dorpat Society Sitzber. d. Dorpater Nat. Gesell., I882), but it did not come into my hands until some time after I had published my first observation (Quart. Jour. Mic. Sci., October, I882), so that, at least from that point of view, my work was quite independent and original. As to the order of the other papers, I agree with Dr. Schaarschmidt, except that I would like to add to his list the papers of Pfurtscheller (Selbstverlag des k. k. Franz Foseph Gymnasiums, I 883), Will, (Bot. Zeit., 52, I 884), Tangl (Sitzb. derk. Akad. der Wiss., Bd. 90, 1884), and Goroschankin (Bot. Zeit., 4I, I883).

As to Dr. Schaarschmidt's claiming, in I 884 , the suggestion of the universality of the occurrence of continuity of the protoplasm in plant-cells, I think that, considicring the state of the subject at that time (April, I883) something may also be said in my favour, for I find in my Royal Society paper (Phil. Trans. Roy. Soc., April, 1883) the following statement:- "Although I am aware of the danger of rushing to conclusions, I cannot but remark that when these results (which were foreshadowed by Sachs and Hanstein, when they discovered the perforation of the sieve-plate) are taken in connection with those of Russow, it appears extremely probable that not only in the parenchymatous cells of pulvini, in phloem parenchyma, in endosperm cells, and in prosenchymatous bast fibres, is continuity established from cell to cell, but that the phenomenon is one of much wider, if not of universal, occurrence." 1

Passing on to the results of Dr. Schaarschmidt's second paper, to which he refers, where he gives a very long list of tissues in which he has demonstrated the existence of a continuity of the protoplasm, I should only wish to remark that while he appears to have observed in a satisfactory manner, and with comparative ease, cases that have appeared to me to be excessively difficult, yet his figures of such continuity are not satisfactory, and in many of them it is the direct and not the indirect continuity which his drawings represent. As I have stated clsewhere $(A r b$. $d$. Bot. Inst. Witrzburg) an examination of fresh unswollen tissue with iodine and chlor. zinc. iod. will always demonstratc the presence of a pit-closing membrane.

I now come to it subject which I approach with some regret, since, in dealing with it, I have to dissent from the expressed opinions of a number of competent observers, and especially do I feel this regret with regard to one of those papers-viz. that by one of the most distinguished

${ }^{1} \mathrm{Mr}$. Dycr has already very kindly alluded to this subject on my behalf. hurry of publication I had not referred to Hartig's paper (February 18, 1885). 